\title{
Conservation of Living Heritage: Elements in Conserving Portuguese Community' Cultural Heritage
}

\section{Intan Syafinar Jamaludin ${ }^{1 *}$, Seow Ta Wee ${ }^{2}$, Indera Syahrul Mat Radzuan ${ }^{1}$}

${ }^{1}$ Department of Real Estate, Faculty of Technology Management \& Business, Universiti Tun Hussein Onn, Batu Pahat, 86400, MALAYSIA

${ }^{2}$ Department of Construction Management, Faculty of Technology Management \& Business, Universiti Tun Hussein Onn, Batu Pahat, 86400, MALAYSIA

*Corresponding Author

DOI: https://doi.org/10.30880/jstard.2021.03.01.002

Re ceived 3 March 2021; Accepted 16 May 2021; Available online 15 June 2021

\begin{abstract}
Rapid urban development in today's cities poses significant threats to heritage site with deterioration and destruction to the heritage by introduced pollution, political war, growing tourism activities, and natural disaster. The concern for the safeguarding of heritage materials and intangible assets has begun with a series of conservation practice that begins with material conservation, values conservation and living conservation approaches. Conservation of living heritage is by emphasizing the role of core community living in traditional settlement inside heritage area. The city of Melaka was declared as World Heritage Site in 2008 and the living heritage in the traditional village of Portuguese Settlement risking with the extinction of cultural heritage in the future due to insufficient cultural heritage conservation management. The purpose of this article is to highlight the conservation elements being used to conserve living heritage particularly for living heritage community. This article was conducted using qualitative research, by using literature and document analysis on relevant literatures, reports and standards. The result revealed the main factors contributed in conserving the living heritage came from elements of community participation, awareness, good communication, capacity building, and stakeholders' involvement. The findings indicated that strong relationship among the elements will build a sustainable community within the heritage site particularly for the core community and at the same time conserving its heritage value.
\end{abstract}

Keywords: Living heritage, cultural heritage, awareness, conservation, community participation, capacity building, stakeholders' involvement

\section{Introduction}

Today's rapidly urbanising cities host most of the world's critical infrastructure, key development assets, political institutions, and significant socioeconomic activities (World Bank, 2015). Uncontrolled growth and informal expansion pose a major threat to social, environment for irreplaceable cultural and natural resources will induce major challenge for conservation efforts (The World Bank, 2009). Urban Conservation Planning in Southeast Asia (2017) emphasised the conservation challenges in the urban cultural heritage for countries like China, India, and other Southeast Asia region is to confront under current urbanisation models; the character of cultural heritage sites is affected directly or indirectly by urbanisation changes as a result of population growth, migration, and infrastructure initiatives. (Themistocleous et al., 2015).

The status of World Heritage Site (WHS) designated by the United Nations Educational, Scientific, and Cultural Organization (UNESCO) aims to promote the recognition, restoration, and conservation of cultural and natural resources around the world (UNESCO, 1972.) However, the development in heritage site has threatened the life of the core community in the heritage site with fast-growing urban development, pollution, deterioration and destruction to heritage, natural disaster, and political war (Meskell, 2013; Ali, 2013; Rössler, 2006). In order to protect the heritage community, The International Centre for the Study of the Preservation and Restoration of Cultural Property (ICCROM) has created a 
Living Heritage Sites programme in 2003. The program's aim was to raise awareness of living heritage perceptions within the context of heritage site management and conservation. In this regard, living heritage is associated with communities and the continuity of practices and traditions (ICCROM, 2015).

The city of Melaka was listed as UNESCO, WHS in 2008 and has become domestic and international tourists' node with the highest recorded number of tourists landing at 16.7 million in 2017 compared to 14 million tourists in 2013 (Melaka Government, 2018). In order to accommodate and attract tourists into its heritage site, the Melaka government has sought solution into rapid urban development (Malacca Town and Country Planning Department, 2015). Rapid urbanisation has jeopardised heritage communities in Melaka WHS and the unique community of the Portuguese, was the most affected by a massive coastal reclamation occurred in front of their coastal area. The reclamation work was carried out without an Environmental Impact Assessment (EIA) and without consultation with the local community, causing fear and discontent among Portuguese community. (Ong, 2017; Rahimah, 2018). The heritage settlement and its community are fragile to urbanisation. Furthermore, with significant threats and inadequate heritage community conservation guideline, it has been the primary concern if the community cultural heritage could sustain in the future. Therefore, the purpose of this article is to highlight the conservation elements being used to conserve living heritage particularly for living heritage of the Portuguese community.

\section{Literature Review}

Community living in heritage site has a long history on its tangible and intangible cultural heritage that reflects the community status and its origin. However, as of today's urbanisation, industrialisation, westernisation and modernisation have endangered the culture, traditions, practice and other intangible cultural heritage, and it is slowly disappearing (Abu Bakar et al., 2014; Lee, 2015). Therefore, community involvement in safeguarding and conserve their cultural heritage by generate, sustain, and transmit are necessary. Many scholars have reviewed the literature on safeguarding and conserving intangible cultural resources (Carayannis, 2005; Kato, 2006; Keitumetse, 2011; Mustafa \& Abdullah, 2013; Nic Eoin \& King, 2013; Petronela, 2016), but only a few have investigated the protection of the core community living in the 'Outstanding Universal Value' heritage site.

\subsection{Heritage and Conservation}

Heritage is characterised by the uses of historical buildings and sites in a community, as well as their value and demand. Heritage, according to Throsby (2001), is a capital asset. It is a social construct that is established within cultural and economic practise, according to Graham (2002).

The approach of conservation varies from culture to culture. Conservation of cultural heritage to the built environment has started from the 1970s, and it has considered the conservation of human and environmental context (Jokilehto, 2009). Heritage conservation is defined as "devoted to the preservation of cultural property for the future" (Munõs-Viñas, 2005). The conservation concepts recently being shifts from "materials" to "values" to "living" based conservation process.

Conservation of heritage started in the early twenty centuries with the monuments are being saved and their fabric is being preserved. (Stanley-Price et al., 1996; Jokilehto, 1986) and it also known as material-based approach. Athens Charter 1931, Venice Charter 1964, World Heritage Convention 1972 are among the guidelines being used for materialbased approach (Braillie, 2009). A material-based approach is an expert-driven approach and cultural significance based on expert values.

The values-based approach focuses on the values that society, which includes a few stakeholder groups, assigns to heritage. The use of this method led significantly to the recognition of local, indigenous communities' (spiritual, religious) relations with their heritage places: the communities' (traditional) management structures and maintenance activities were considered, and the communities were active in the conservation process (Poliaus, 2014). Burra Charter 1979 and Nara Document on Authenticity 1994 are among the guideline being practice in value-based approach. The value-based approach is cultural significance guided by expert values that includes stakeholder participation, consultation and dialogue (Braillie, 2009).

Conservation of living based also known as people-based conservation aims at the community on the community's well-being takes precedence over tangible heritage. The concept of heritage conservation can be defined as all measures and actions aimed at safeguarding, preserve, maintain, protect, and adopt of all assets, natural, cultural, tangible and intangible heritage simultaneously warranting its accessibility to present and future generation. The fundamental of heritage conservation is to identify, record, analyse, and protecting the heritage values.

Living-based conservation, also known as people-based conservation, focuses on the community's well-being rather than tangible heritage. The focus of heritage practitioners has changed from tangible cultural heritage to human capacity building and social benefits for the society to engage in the heritage process thanks to intangible cultural heritage.

\subsection{Living Heritage}

Living heritage refers to the living dimensions inside the heritage site and introduces the concept of continuity, particularly the continuity of the community's connection with heritage. ICCROM developed living heritage programme 
that empathises on living heritage that benefits people's interest and can be adapted to any heritage category (ICCROM, 2003). The core community is the community that sustains the original function of heritage, have strong ownership for heritage, and caring for heritage as its own inherent (Poliaus, 2014) as shown in Figure 1 below. The core community is the principal role in conservation heritage development. It is the continuous process of developing tangible and intangible cultural heritage expressions in response to changing conditions, as expressed through (traditional) expertise, management systems, and maintenance practises; and it is the continuous process of caring for heritage by the community as stated over (traditional) knowledge, management systems, and maintenance practises.

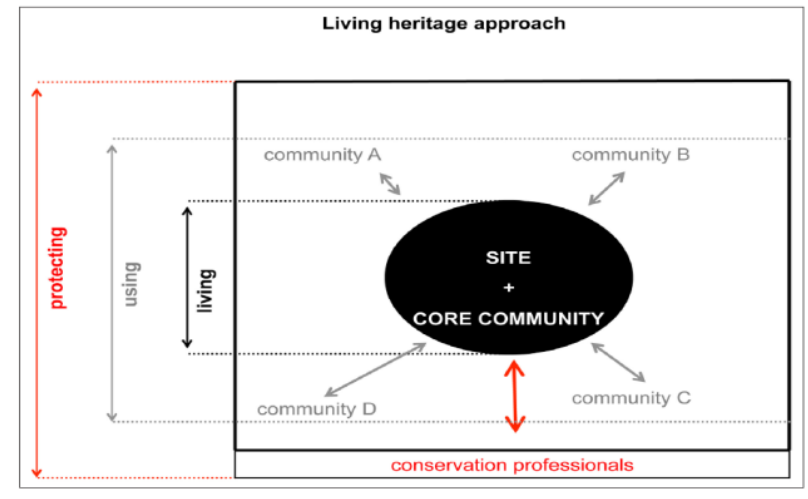

Fig. 1 - Living heritage approach (source: Poliaus, 2014)

A living heritage site, is a site that seeks to recreate historical conditions in order to replicate a time period in the past, providing tourists with an experiential view of history. It's a place that recreates the conditions of a society, historical time, or natural setting. In terms of concept, it's a place with defined boundaries and a permanent local community. Therefore, the community lives inside living heritage site is different from the surrounding community because it has a special relationship with the site and its continuing functionality. The community considers the site to be their home because it gives them a sense of belonging, comfort, and meaning in their lives. (ICCROM, 2015; Poliaus, 2014).

The elements of continuity for living heritage approach can be categorised into three, namely: community connections, cultural expressions (intangible and tangible), and continuity of care through traditional or established means (ICCROM, 2003). Living Heritage Approach is an enhancement on the two current approaches, namely, values based and fabric based and can be adapted with any category of heritage.

In response to the changing world faces by the heritage community, the community needs to evolve, but at the same time, need to conserve its original heritage functions. The communities at Portuguese Settlement currently facing major coastal reclamation works in front of their habitat and the reclamation activity. Coastal reclamation works will cause alteration in social, cultural, ecosystem and economic activities (Kay \& Alder, 1999; Xu \& Wang, 2003; Kaparawi \& Abdul Latif, 2008; Rene, 2012) as well as negative impacts on human health (Mohd Nadzir et al., 2014; Petersmack \& Wilkerson, 2003; Xu \& Wang, 2003). Furthermore, a study by Abu Bakar et al. (2014) also shows that heritage communities in Melaka encountered socio-economic inequality, strong ethnic enclaves, acculturations and deculturation and impact of modernisation. Unlike other local community, the heritage communities are fragile to any urban development as it jeopardises their tradition, culture and heritage. Hence, in order to conserve the core community at Portuguese Settlement, living heritage is a suitable approach to conserve and sustain the community cultural heritage for the continuity of its heritage for the future generation. Therefore, in the following section will discuss elements of conservation to safeguard core community living in heritage site.

\section{Elements in Conserving Community's Cultural Heritage}

Community living in WHS has a long history on its tangible and intangible cultural heritage that reflects the community status and its origin. However, as of today's urbanisation, industrialisation, westernisation and modernisation have endangered the culture, traditions, practice, language, cultural heritage, and it is slowly disappearing (Abu Bakar et al., 2014; Lee, 2015). Living heritage conservation necessitates a thorough understanding of the local communities in terms of temporal and spatial characteristics.

The need to conserve community cultural heritage imposed by of conservation elements in safeguarding community cultural heritage as communities has been the founder of heritage. Engagement of people-based approach is the key to conserve cultural heritage, and Smith, Morgan and van der Meer (2003) justified that comprehensive engagement refers to safeguarding that community members and shareholders are involved in cultural heritage assessments and in management decisions as well as referred on impacts and opportunities. 
From previous research and studies, researcher has identified 5 elements to conserve community cultural heritage as shown in figure 2 below, the elements are community participation, awareness, communication, capacity buildings, and stakeholders' involvement.

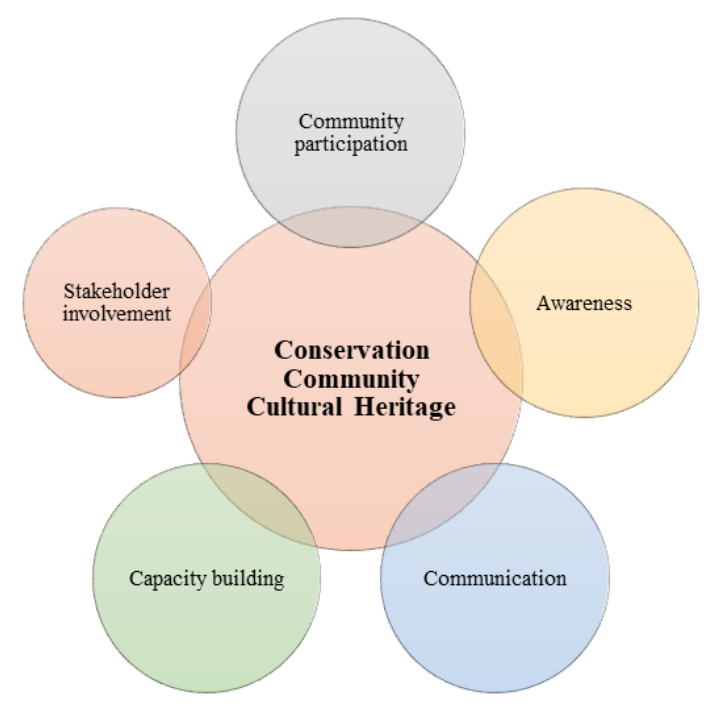

Fig. 2 - Elements in conservation of community cultural heritage

\subsection{Community Participation}

Community participation and community conservation involvement in heritage has been well embedded in contemporary conservation practice. The potential of heritage to play an active role in the lives of communities and to bring benefits to people is increasingly widely recognised. Communities are being engaged in the process of making conservation and management decisions about themselves and their heritage, as well as the process of putting those decisions into action. (Court \& Wijesuriya, 2015). Through active participation and involvement of core community through any stages of planning, implementation, and development progress would encourage sustainable community for that particular heritage site similarly will be able to safeguard their cultural heritage by voicing out their concerns on issues regarding to cultural heritage (Keitumetse, 2011; Marschalek, 2008; Mathbor, 1997; Poulios, 2014; Sapu, 2003).

The principles of conservation and participatory planning focus on energising all stakeholders involved in the process (cultural, social, economic, and environmental), and the public's and community members' active engagement is crucial in preserving heritage assets. (Spiridon, 2013). Wijesuriya (2015) has emphasised culture or living heritage in his study, recognising the impact of heritage on people's daily lives and how it can enhance their quality of life, reflecting on both the past and present and increasing the importance of cultural products.

Participation in World Heritage Sites has strengthened the community's sense of belonging, facilitated the creation of social networks, and instilled a greater appreciation and understanding of local values. (McCool \& Martin, 1994; Tosun, 2002). Local communities play an important role in restoring and sustaining the heritage site. Their involvement in heritage management helps them prosper economically and increases their overall quality of life. (Sirisrisak, 2009).

\subsection{Awareness}

Creating cultural heritage awareness and promotion is a critical topic for educating the general public about the urgent need for cultural heritage information acquisition. Living heritage community should also be empowered to appreciate their own cultural heritage and appreciate it. Shimray (2019) through his research has defined public awareness can be increase through promoting cultural heritage by means of festivals celebration, education, heritage trail and walk.

Awareness is an important part of protecting cultural heritage. People living near to cultural heritage site may cause damage if they not have enough conscious (UNESCO, 1972). For community living in heritage site, the absence of awareness of intangible cultural heritage will cause these intangible cultural heritages being extinct. While, if the awareness of tangible cultural properties is insufficient, these properties will not be protected and will be destroyed.

The study by Shankar and Swamy (2013) indicated involvement of stakeholders' participation play vital role creating awareness in heritage conservation. Rajangam (2016) conducted an awareness project study in which the public in Naksyah was exposed to Neighbourhood Diaries from the heritage community with the aim of inspiring community pride and fostering local identity through cultural heritage awareness. The aims were to capture and present the essence of rapidly vanishing place history, as well as to raise public awareness of local residents' fears about rapid change 
(Rajangam, 2016). The initiatives are noteworthy because they are sincere efforts to involve community in a conversation about heritage and conservation.

\subsection{Communication}

Interdisciplinary teamwork necessitates communication and participation in order to define the particular sets of expertise and skills necessary to resolve specific preservation and conservation problems. Communication, according to the Budapest Declaration, refers to raising public consciousness, engagement, and respect for World Heritage through communication. (WHC, 2005).

Communication and education were highlighted in the World Heritage Collaborations Project, especially computerbased communication techniques. (Albert, 2012). Similarly, Michela Ott and Pozzi (2011) showed the use Information and Communication Technology in heritage conservation able contribute to innovate, tune, channel and improve conservation needs when work together with education practitioner. On the other hand, communication is impossible without community participation, as community members have to communicate and correspondence with organizations, as well as local officials in order to engage in conservation programs (Hung et al., 2011 \& Aas et al., 2005).

Overdevelopment of heritage sites poses a real threat to conservation and preservation activities, so stakeholders must balance top-down and bottom-up approaches (Erlewein, 2017), promoting communication between and among community members to reflect their desires, needs, and concerns. Direct communication with stakeholders and consideration of object-related principles will offer evidence that universal codes and indirect historical experience cannot. Therefore, good communication between stakeholder and community, excellent communication medium such as education and ICT able to transfer right information and conserve its heritage value.

\subsection{Capacity Building}

The World Heritage Committee presented a capacity-building strategy in 2011 (UNESCO, 2011), which is being applied by ICCROM in partnership with the other advisory bodies, ICOMOS and IUCN (ICCROM, ICOMOS, IUCN, 2014). The plan seeks to extend the definition of training to include capacity building. Not only must human capital be created, but also administrative and operational coordination, as well as legal and regulatory mechanisms and their applicability must be considered. (ICCROM, ICOMOS, IUCN, 2014).

Diverse professionals and heritage associations will commit to a capacity-building initiative in heritage conservation, exchanging their perspectives and learning from others in order to advance practise by equipping them with the requisite skills and tools to collaborate more successfully with communities through current management processes. (Court \& Wijesuriya, 2015). The other input would be local community collaboration with number of other local groups, providing training and employment opportunities to disadvantaged young people while also creating a technical community for the upkeep and maintenance of the heritage (Loffredo, 2013).

An important issue in capacity building strategies is the integration of all stakeholders and the development and implementation of appropriate conservation and management programmes. The aim is to guarantee the continuity of the significance, in the first case, and the building up of consciousness of the significance, in the second.

\subsection{Stakeholders' Involvement}

The principle of collaborative conservation and participatory conservation which focus on stimulating all stakeholders engaged in the process (cultural, social, economic and environmental) and the active participation of the public and community members is critical in safeguarding the heritage assets (Spiridon, 2013).

A study by Blake (2015) highlights the conservation of community's intangible cultural heritage is tightly bound with the government as they are involved in setting policies and taking safeguarding measure. In a particular situation, when governmental agencies may lack expertise, this is where stakeholder particularly NGO to bridge the gap in implementing conservation activities (Blake, 2015).

Overall, a strong attempt to conserve cultural heritage necessitates effective coordination that promotes communication and engagement among local community and other stakeholders. Stakeholders should be responsive to the cultural diversity of the community, and community participation demonstrates the rights to access and engage in cultural life alongside with other individual rights such as access to information and education, freedom of speech, selfmobilisation. As a result, it provides important tools for the preservation and development of living heritage in physical, economic and social terms.

\section{Conclusion}

As of today's urbanisation, industrialisation, westernisation and modernisation have endangered the culture, traditions, practice, language, cultural heritage, and it is slowly disappearing. Living heritage residing in heritage site is slowly diminishing of intangible heritage culture in the community. However, with the right conservation elements such as community participation, awareness, communication, capacity building and stakeholders' involvement will be able to conserve community cultural heritage. 
Engaging the community in phases of planning, execution, and construction advancement related to their cultural heritage or living place will help to preserve the community living in heritage sites. Nevertheless, a good teamwork from community' active participation and stakeholders' involvement, tied together with good communication medium will further enhance the heritage conservation for the community.

In the process of conserving community cultural heritage, it is essential to introduce heritage awareness to the public as well as living heritage community to promote and safeguarding cultural heritage. However, in order to strengthen the conservation practice, capacity building is required for heritage organizations to share their experience and knowledge with living heritage community so that it will effectively and persevere conserving community cultural heritage.

All and all, conservation elements such as community participation, awareness, communication, stakeholders' involvement, and capacity building are indispensable without one another. By understanding challenges facing by the community and assets of its cultural heritage, conservation elements able to safeguard, protect and preserve heritage value. Heritage conservation is important process that will leaves an invaluable resource for future generations.

\section{Acknowledgements}

The author would like to thank Universiti Tun Hussein Onn Malaysia (UTHM) for the opportunity to publish the paper, to my main supervisor and co-supervisor for their endless support.

\section{References}

[1] Aas, C., Ladkin, A., \& Fletcher, J. (2005). Stakeholder collaboration and heritage management. Annals of Tourism Research, 32(1), 28-48

[2] Abu Bakar, A., Osman, M. M., Bachok, S., \& Ibrahim, M. (2014). Analysis on Community Involvement Level in Intangible Cultural Heritage: Malacca Cultural Community. Procedia - Social and Behavioral Sciences, 153, 286297

[3] Albert, M.T. (2012). Perspectives of World Heritage: towards Future-oriented Strategies with the Five 'Cs'. World Heritage Paper 31: Community Development through World Heritage. Paris: UNESCO. pp. 32-38

[4] Blake, J. (2015). Safeguarding intangible cultural heritage in the urban environment: Some experiences gained from implementing UNESCO's 2003 convention. In S. Labadi \& L. William (Eds.). Urban Heritage, Development and Sustainability. London \& New York: Routledge. pp.114-133

[5] Braillie, Brigit. (2009). Living Heritage Handbook. Living Heritage Sites Programme. New York: ICCROM

[6] Campbel, M. L., \& Vainio-Mattila, A. (2003). Participatory Development and Community-Based conservation: Opportunities Missed for Lessons Learned? Human Ecology, 31(3), 417-437

[7] Carayannis, E. G. (2005). Measuring intangibles: managing intangibles for tangible outcomes in research and innovation. International Journal of Nuclear Knowledge Management, 1(1/2), 49

[8] Cook, A. \& Hyslop, J. (2004). Sustainable communities. In T. Mottershead (Ed.), Sustainable development in Hong Kong. Hong Kong: Hong Kong University Press. 269-290

[9] Court, S. and Wijesuriya, G. (2015). People-Centred Approaches to the Conservation of Cultural Heritage: Living Heritage. International Centre for the Study of the Preservation and Restoration of Cultural Property. ICCROM. https://doi.org/10.1016/0031-8663(75)90031-9

[10] Dijkgraaf, C. (2003). How World Heritage Sites Disappear: Four Cases, Four Threats. World Heritage Paper 13. Linking Universal and Local Values: Managing a Sustainable Future for World Heritage conference. Netherlands: UNESCO. pp. 32-35

[11] Erlewein, S. N. (2017). Culture, Development and Sustainability: The Cultural Impact of Development and Culture's Role in Sustainability. In Albert, M.T. (Ed.). Going Beyond in Perceptions of Sustainability in Heritage Studies No. 2. Cham: Switzerland

[12] Graham, B. (2002). Heritage as knowledge: Capital or culture? Urban Studies, 39(5-6), pp. $1003-1017$.

[13] Hamstead, M.P., Quinn, M.S. (2005). Sustainable community development and ecological economics: theoretical convergence and practical implications. Local Environ. 10 (2), 141-158

[14] Hung, K., Sirakaya-Turk, E., \& Ingram, L. J. (2011). Testing the efficacy of an integrative model for community participation. Journal of Travel Research, 50(3), 276-288

[15] Hsueh, S.L., \& Yan, M.R. (2011). Enhancing sustainable community developments a multi-criteria evaluation model for energy efficient project selection. Energy Procedia 5 (0), 135-144

[16] ICCROM (2015). "Promoting people-centred approaches to conservation: living heritage," available at: www.iccrom.org/wp-content/uploads/PCA_Annexe-1.pdf

[17] Jokilehto, J. (1999). A Century of Heritage Conservation. Journal of Architectural Conservation, 5(3), 14-33

[18] Kato, K. (2006). Community, Connection and Conservation: Intangible Cultural Values in Natural Heritage-the Case of Shirakami - sanchi World Heritage Area. International Journal of Heritage Studies, 12(5), 458-473

[19] Kay, R., \& Alder, J. (2012). Coastal Planning and Management, Second Edition 
[20] Keitumetse, S.O. (2011). Sustainable Development and Cultural Heritage Management in Botswana: Towards Sustainable Communities. Sustainable Development. 19, 49-59

[21] Kline, E. (1995). Sustainable Community Indicators Report. Consortium for Regional Sustainability, Tufts University, Medford, MA

[22] Lee, J. S. (2015). Measuring the benefits of the Intangible Cultural Heritage Hall in Jeonju Korea: Results of a Contingent Valuation Survey. Journal of Cultural Heritage, 16(2), 236-238

[23] Loffredo, A. (2013). Noi del Rione Sanità. Rome: Mondadori

[24] Malacca Town and Country Planning. (2015). Coastal Land Reclamation in Malacca. Malacca Town and Country Planning

[25] Marschalek, I. (2008). The concept of participatory local sustainability projects in seven Chinese villages. Journal of Environmental Management, 87(2), pp. 226-235

[26] Mat Radzuan, I. S. \& Yahaya, A. (2016). Assessing Cultural Heritage Potential: A Framework to Incorporate Incentives Programme into Heritage Management Strategies. The Social Science, 11(12), 2916-2921

[27] Mathbor, G. M. (1997). The importance of community participation in coastal zone management: A Bangladesh perspective. Community Development Journal, 32(2), 124-132

[28] McCool, S. F., \& Martin, S. R. (1994). Community attachment and attitudes toward tourism development. Journal of Travel Research, 32(3), 29-34

[29] Melaka Government. (2018). Statistic of Tourist Landing in State of Melaka

[30] Munõs-Viñas, S. (2005). Contemporary Theory of Conservation, Elsevier Butterworth-Heinemann, Oxford

[31] Nadzir, N. M., Ibrahim, M., \& Mansor, M. (2014). Impacts of Coastal Reclamation to the Quality of Life: Tanjung Tokong Community, Penang. Procedia - Social and Behavioral Sciences, 153, 159-168

[32] Nic Eoin, L., \& King, R. (2013). How to develop Intangible Heritage: The case of Metolong Dam, Lesotho. World Archaeology, 45(4), 653-669

[33] ODPM (2003). Sustainable Communities: Building for the Future. The Office of the Deputy Prime Minister, UK.

[34] Ong, P. L. (2017). Community involvement for sustainable world heritage sites: The Melaka case, 35(1), 59-76.

[35] Petronela, T. (2016). The Importance of the Intangible Cultural Heritage in the Economy. Procedia Economics and Finance, 39, 731-736

[36] Power, A., \& Smyth, K. (2016). Heritage, health and place: The legacies of local community-based heritage conservation on social wellbeing. Health and Place, 39, 160-167

[37] Poulios, I. (2014). Discussing strategy in heritage conservation, Journal of Cultural Heritage Management and Sustainable Development, 4(1),16-34

[38] Rahimah, A. A. (2018). Heritage Conservation: Authenticity and Vulnerability of Living Heritage Sites in Melaka State. Kajian Malaysia, 35(1), 39-58

[39] Rahimah Abdul Aziz, Halimaton Saadiah Hashim, Ong Puay Liu, Geraldine Chan Kim Ling, Sarah Aziz, Ruslin Amir and Sharina Abdul Halim. (2015). Laporan penglibatan pihak berkepentingan dalam governans pemuliharaan warisan: Bandaraya Melaka Bersejarah

[40] Raj Isar, Y. (2004). Tangible and intangible heritage: are they really Castor and Pollux?. Paper presentation presented at Conference held on the occasion of 20th Anniversary of the founding of the Indian National Trust for Art and Cultural Heritage (INTACH), New Delhi, India

[41] Rajangam, K. (2016). Linking people and heritage Lessons from community engagement initiatives in India. In Chitty, G. (Ed.). Heritage, Conservation and Communities in Engagement, Participation and Capacity Building. University of Ulster: Routledge

[42] Rogers, M., Ryan, R. (2001). The triple bottom line for sustainable community development. Local Environ. 6 (3), 279-289

[43] Rojas, E. (2015). The sustainable conservation of urban heritage. Urban Heritage, Development and Sustainability International frameworks, national and local governance. Routledge. New York

[44] Saleh, Y., Mat Said, Z., Nayan, N., \& Che Leh, F. (2007). Survival Warisan Budaya Dalam Sektor Pelancongan. Satu Tinjauan Di Melaka. Perak: Universiti Pendidikan Sultan Idris

[45] Sapu, S. (2003). Conserving Heritage In East Asian Cities: Planning For Continuity and Change Community Participation in Heritage Conservation

[46] Shankar, B., and Swamy, C. (2013). Creating Awareness for Heritage Conservation in the City of Mysore: Issues and Policies. International Journal of Modern Engineering Research, 3(2), pp. 698-703

[47] Shimray, S. R. (2019). Ways to Create Awareness on Cultural Heritage: An overview. Journal Library Philosophy and Practice

[48] Sirisrisak, T. (2009). Conservation of Bangkok old town. Habitat International, 33(4), 405-411

[49] Smith, L. (ed.) (2006). Cultural Heritage: Critical Concepts in media and Cultural Studies. New York: Routledge

[50] Smeets, R. (2003). Intangible Cultural Heritage and Its Link to Tangible Cultural and Natural Heritage

[51] Spiridon, P. \& Sandu, I. (2015). Conservation of cultural heritage: from participation to collaboration. Encatc Journal of Cultural Management and Policy, 5(1), 43-52 
[52] Stanley-Price, N., Tally, M.K. \& Melucco Vaccaro, A. (1996). Historical and Philosophical Issues in the Conservation of Cultural Heritage.The Getty Conservation Institute, Los Angeles, CA

[53] Sully, D. (2015). Conservation theory and Practice Materials, values, and People in Heritage Conservation. The International Handbooks of Museum Studies: Museum Practice. John Wiley \& Sons

[54] Tosun, C. (1999). Towards a typology of community participation in the tourism development process. Anatolia, $10(2), 113-134$

[55] Themistocleous, K., Alexakis, D. D., Hadjimitsis, D. G., Cuca, B., Agapiou, A., Lysandrou, V., \& Sarris, A. (2015). Impact of urban sprawl to cultural heritage monuments: The case study of Paphos area in Cyprus. Journal of Cultural Heritage, 16(5), 671-680

[56] UNESCO (1972). UNESCO Convention concerning the protection of world cultural and natural heritage

[57] Wang, X., Chen, W., Zhang, L., Jin, D., \& Lu, C. (2010). Estimating the ecosystem service losses from proposed land reclamation projects: A case study in Xiamen. Ecological Economics, 69(12), 2549-2556

[58] WCED (1987). Our Common Future. The World Commission on Environment and Development, Oxford

[59] Wijesuriya, G. (2005). The past is in the present: perspectives in caring for Buddhist heritage sites in Sri Lanka. Conservation of Living Religious Heritage: Papers from the ICCROM 2003 Forum on Living Religious Heritage: Conserving the Sacred, ICCROM, Rome, 31-43

[60] World Bank. (2015). East Asia’s Changing Urban Landscape. World Bank 